\title{
Effect of Steroid Therapy on Growth hormone in Children with Nephrotic Syndrome A.A.Abd El-hameed ${ }^{1}$, S.A.El-Gendy ${ }^{1}$, E.R.Abd El-gawaad ${ }^{2}$, R.A.Elsayed ${ }^{1}$ and H.H.Mahmoud $^{1}$ \\ ${ }^{1}$ pediatrics, Dept., Faculty of Medicine, Benha Univ., Benha, Egypt \\ ${ }^{2}$ clinical and chemical pathology, Dept., Faculty of Medicine, Benha Univ., Benha, Egypt \\ E-mail: Mahmoud@yahoo.com
}

\begin{abstract}
Background: Nephrotic syndrome is the most frequent kidney-related condition in the United States today, providing a severe health risk. The cornerstone of therapy is still corticosteroids. Protein deficiency was a major cause of linear growth retardation in nephrotic individuals before steroids were administered. The goal of our research was to see how corticosteroids affected growth hormone in children with nephrotic syndrome. Methodologies: From February to December 2020, a cross-sectional research was conducted on children with nephrotic syndrome who visited the Benha University Nephrology clinic. After receiving written agreement from the patients' parents, the research included 36 patients with nephritic syndrome of both sexes, divided into two groups: corticosteroid response group and corticosteroid plus other immunosuppressive medications group. The following conditions were applied to all of the instances in the study: Growth hormone level in blood was measured after a thorough history, full clinical examination, and laboratory testing. Results: The majority of our NS patients (66.7\%) were on corticosteroid medication, while 33.3 percent were on corticosteroid plus immunosuppressive medication, according to our research. Complete remission was $1(2.8 \%)$, steroid dependent was $20(55.5 \%)$, rare recurrence was $3(8.4 \%)$, and corticosteroid resistant was 12 in our research (33.3). According to the findings of the present research, small stature accounted for 15 percent of the cases analysed (41.7 percent ). The G.H distribution in the examined cases was found to vary between 0.04 and $2.80 \mathrm{ng} / \mathrm{ml}$, with a mean of 0.760 .86 . The distribution of elicited growth hormone in the examined patients varied from 1.17 to $14.60(\mathrm{ng} / \mathrm{ml})$, with a mean of 5.282 .81 . According to this research, the distribution of activated growth hormone categories among the analysed patients was as follows: borderline (10.78\%), normal (6.17\%), and subnormal (20\%). (55.6 percent). There was a statistically significant negative connection between cumulative steroid dosage and mortality in the present trial (growth hormone and provocated Growth hormone). Conclusion: The majority of children with nephrotic syndrome exhibited a height disadvantage. Children with nephrotic syndrome may have growth retardation as a result of chronic steroid therapy. In most instances of NS, growth hormone levels are below normal. Corticosteroid cumulative doses have a negative impact on linear growth.
\end{abstract}

Key words: Corticosteroid, Growth hormone, Nephrotic syndrome, Evaluation.

\section{Introduction}

The most clinically frequent kidney-related condition nowadays is nephrotic syndrome, which poses a major danger to physical health. Immune dysfunction is the key pathogenic and initiating element in its aetiology. At the same time, patients are often malnourished as a result of the loss of a huge number of plasma proteins [1].

Massive proteinuria, hypoalbuminemia, and oedema are all symptoms of childhood nephrotic syndrome. The illness has a relapsing and remitting course in the majority of people. The cornerstone of therapy is still corticosteroids. For the first four to six weeks, steroids are administered on a daily basis, followed by alternate day dosage for another four to six weeks. Relapses are treated with daily corticosteroids until remission is achieved, then alternate-day medication is started and decreased over time. A small percentage of patients remain steroid-dependent and need long-term use of alternate-day steroids, sometimes with the addition of steroid sparing medicines. Relapses are connected with hazards such as sepsis, thrombosis, malnutrition, dyslipidemia, and hypovolemia, whereas excessive dosages of steroids have been linked to side effects such as hypertension, diabetes, and behavioural problems [2].

Protein deficiency owing to low appetite, loss owing to proteinuria, and malabsorption owing to gastrointestinal tract oedema were all major causes of linear growth retardation in nephrotic patients prior to the administration of steroids. Corticosteroids, on the other hand, are thought to be the primary reason in the current situation. Corticosteroids' negative effects on linear development in children have been clearly established. Corticosteroids are hypothesised to impede development via a variety of processes, including reduced growth hormone production and insulin-like growth factor-1 (IGF-1) activation on developing bones. These benefits are most noticeable with longterm and daily dose regimens, and published research suggests that alternate-day dosage has negligible growth impacts [3,4]. This is in contrast to what we've seen in our patient group, where growth failure is evident even in individuals taking alternate-day steroids.

The goal of our research was to see how corticosteroids affected growth hormone in children with nephrotic syndrome.

\section{Patients and Methods}

Cross sectional study was performed on children attending in Benha University Nephrology clinic with nephrotic syndrome in the period from February 2020 to December 2020. 


\subsection{Inclusion criteria}

- the study were included 36 cases of children with nephrotic syndrome:

- Both sexes.

- Age within 1 to 18 years

- Diagnosed as nephrotic syndrome according to the criteria of International Study of Kidney Disease in Children (ISKDC)

- Steroid therapy for at least four months.

\subsection{Exclusion criteria}

- Patients were lost to follow up.

- Patient with history of intrauterine growth retardation.

- Patient with other systemic or endocrine disease.

- Patient with dysmorphic triats or central nervous system irradiation

- Patient with family history of short statue.

\subsection{Samples}

It was comprised 36 patients with nephritic syndrome of both sex after obtaining informed consent from patients parents as follow:

- Corticosteroid response group

- Corticosteroid with other immunosuppressive drugs group

\subsection{Methods}

Data were collected by physician on a standarized form.

All cases included in the study were subjected to the following:

\section{A-Careful history taking regarding: \\ Detailed history taking:}

Detailed history taking including; presenting complaint, history of present illness including duration of disease, protocole of management and classification of disease according to response to corticosteroids, history of past illness including all significant illness since infancy, antenatal history, natal history, dietetic history, developmental history and immunization history.

\section{B-Full clinical examination:}

\section{1-General examination including:}

- General comment on patient conscious and mental state

- Vital signs: pulse, blood pressure, respiratory rate and temperature.

- Hand to head to foot examination

- Assessment of height, weight and body mass index BMI using growth curves based on the World Health Organization Child Growth Standards (2006).

2-Systemic examination:

- Chest examination

- Heart examination

- Abdominal examination.

- Neurological examination.

\subsection{Laboratory work}

- Complete blood count.

- Lipid profile.

- Total protein in 24 hour urine.

- Protein creatinine ratio

- Kidney function tests

- Special investigation according to each case.

- Growth hormone level in serum.

Human Growth Hormone (hGH) ELISA Kit

For the quantitative determination of human growth hormone (hGH) concentrations in serum.

Intended Use

This Human GH ELISA Kit is to be used for the in vitro quantitative determination of human growth hormone (hGH) concentrations in serum.

\subsection{Ethical consideration}

Ethical permission for the study were obtained from the parents who were be fully informed about all study procedures and their consent were obtained prior to the children enrollment in the study.

This study was approved by the Ethical Committees of Faculty of Medicine, Benha University Hospital.

\subsection{Statistical Analysis}

Data analysis was performed using the software SPSS (Statistical Package for the Social Sciences) version 24. Quantitative variables were described using their means and standard deviations. Categorical variables were described using their absolute frequencies and were compared using Chi square test and fisher exact test when appropriate. KolmogorovSmirnov (distribution-type) tests were used to verify assumptions for use in parametric tests. To compare continuous quantitative data of two groups, Mann whitney test (for non-normally distributed data) and independent sample $\mathrm{t}$ test (for normally distributed data) were used. The level statistical significance was set at $5 \%(\mathrm{P}<0.05)$.

\section{Results}

This table shows that, female were $14(38.9 \%)$ and male were $22(61.1 \%)$.only2patients $(5.6 \%)$ had positive history of nephrotic syndrome. Family history of short stature distribution among the studied cases, negative were $(100 \%)$.Age ranged between 3.5 and 13 years with mean $(7.65 \pm 2.34)$.year and age of onset of the disease ranged between 1 and 9 with mean (4.15 \pm 1.90 ) year Table (1).

This table shows that Cortico Steroid $66.7 \%$ while Cortico Steroid and other immunosuppressive drugs were 12 (33.3) Table (2).

This table shows that response to CorticoSteroids distribution among the studied cases, complete remission were $1(2.8 \%)$, steroid dependant were 20 $(55.5 \%)$, infrequent relapse were $3(8.4 \%)$ and CorticoSteroid resistant were 12 (33.3) (Table 3).

This table shows that Height ranged between 55 and $151 \mathrm{~cm}$ with mean $(108.31 \pm 29.06)$. Weight ranged between 12 and $105 \mathrm{~kg}$ with mean $(32.08 \pm 15.75)$. BMI 
ranged between 3.50 and $62.50 \mathrm{~kg} / \mathrm{m}^{2}$ with mean $(29.29$ $\pm 15.93)$. Height categories distribution among the studied cases, normal were $20(55.6 \%)$, short were 15 $(41.7 \%)$ and tall were $1(2.8 \%)$. Weight categories distribution among the studied cases, normal were 23 $(63.9 \%)$, obese were $9(25 \%)$, over weight were 3 $(8.3 \%)$ and under weight were $1(2.8 \%)$ (Table 4).

This table shows that G.H distribution among the studied cases ranged between 0.04 and $2.80 \mathrm{ng} / \mathrm{ml}$ with mean $(0.76 \pm 0.86)$ (Table 5).

This table shows that Provocated growth hormone distribution among the studied cases, ranged between 1.17 and $14.60(\mathrm{ng} / \mathrm{ml})$ with mean $(5.28 \pm 2.81)$ (Table 6).

This table shows that Activated growthhormone categories distribution among the studied cases, borderline were $10(27.8 \%)$, normal were 6 (16.7\%) and sub normal were $20(55.6 \%)$ (Table 7).

This table shows that protein in $24 \mathrm{~h}$ urine distribution among the studied cases ranged between 3.5 and $8(\mathrm{gm} / \mathrm{dl})$ with mean $(6.22 \pm 1.44)$. Urea distribution among the studied cases, ranged between 17 and $33(\mathrm{mg} / \mathrm{dl})$ with mean $(26.80 \pm 4.98)$. creat distribution among the studied cases, ranged between 0.30 and $0.90(\mathrm{mg} / \mathrm{dl})$ with mean $(0.64 \pm 0.19)$. Haemoglobin distribution among the studied cases, ranged between 7 and $12.3(\mathrm{gm} / \mathrm{dl})$ with mean $(10.59 \pm$ 1.15). Triglycerides distribution among the studied cases ranged between 152 and $173(\mathrm{mg} / \mathrm{dl})$ with mean $(160.80 \pm 6.14)$. Cholesterol distribution among the studied cases, ranged between 185 and $231(\mathrm{mg} / \mathrm{dl})$ with mean (212.40 \pm 12.70) (Table 8).

This table shows that CUMULATIVE DOSE OF STEROID distribution among the studied cases ranged between 0.002 and 2.610 with mean $(1.06 \pm 0.66)$ (Table 9).
There were no statistically significant difference between corticosteroid group and corticosteroid with other immunosuppressive drugs group regarding demographic data (Table 10).

There was no statistically significant difference between corticosteroid group and corticosteroid with other immunosuppressive drugs group regarding anthropometric measurements (Table 11).

Mean value of growth hormone was significantly lower among corticosteroid group than corticosteroid with other immunosuppressive drugs group (0.60, 1.08) $\mathrm{p}$ value $=0.016$ (Table 12).

Mean value of provocated Growth hormone was significantly higher among corticosteroid group than Steroid with other immunosuppressive drugs group $(5.21,5.30) \mathrm{p}$ value $=0.025$ (Table 13).

There was no statistically significant difference between corticosteroid group and corticosteroid with other immunosuppressive drugs group regarding propagated growth hormone distribution (Table 14).

There was no statistically significant difference between corticosteroid group and corticosteroid with other immunosuppressive drugs group regarding CUMULATIVE DOSE OF STEROID (Table 15).

This table shows that there were statistically significant positive correlation between CUMULATIVE DOSE OF STEROID and WT, and negative correlation between CUMULATIVE DOSE OF STEROID and (HT, growth hormone and provocated Growth hormone) while there were no statistically significant correlation between CUMULATIVE DOSE OF STEROID and the other variables (Table 16).

Table (1) Demographic data distribution among the studied cases.

\begin{tabular}{llcc}
\hline & & No. & \% \\
\hline sex & female & 14 & 38.9 \\
male & 22 & 61.1 \\
$\begin{array}{l}\text { Family history of } \\
\text { nyndrome }\end{array}$ & $\begin{array}{l}\text { negative } \\
\text { positive }\end{array}$ & 34 & 94.4 \\
$\begin{array}{l}\text { Family history of } \\
\text { short stature }\end{array}$ & negative & 2 & 5.6 \\
& & 36 & 100 \\
$\begin{array}{l}\text { Age (years) } \\
\text { age of onset of the disease (years) }\end{array}$ & Range & Mean \pm SD \\
\hline
\end{tabular}

Table (2) protocol of management among the studied cases.

\begin{tabular}{llcc}
\hline & & No. & $\%$ \\
\hline drugs & $\begin{array}{l}\text { Cortico Steroid } \\
\text { Cortico Steroid } \\
\text { and other immunosuppressive drugs }\end{array}$ & 24 & 66.7 \\
& & 12 & 33.3 \\
\hline
\end{tabular}


Table (3) response to CorticoSteroids among the studied cases.

\begin{tabular}{llcc}
\hline & & No. & \% \\
\hline response to steroid & complete remission & 1 & 2.8 \\
& CorticoSteroid dependant & 20 & 55.5 \\
& infrequent relapse & 3 & 8.4 \\
& CorticoSteroid resistant & 12 & 33.3 \\
\hline
\end{tabular}

Table (4) growth parameters distribution among the studied cases.

\begin{tabular}{|c|c|c|c|}
\hline & & Rang & Mean \pm SD \\
\hline \multicolumn{2}{|l|}{ Height (cm.) } & $80-151$ & $108.31 \pm 29.06$ \\
\hline \multicolumn{2}{|l|}{ Weight (kg) } & $12-105$ & $32.08 \pm 15.75$ \\
\hline \multirow{2}{*}{\multicolumn{2}{|c|}{ BMI $\left(\mathrm{kg} / \mathrm{m}^{2}\right)$}} & $3.50-62.50$ & $29.29 \pm 15.93$ \\
\hline & & No. & $\%$ \\
\hline \multirow[t]{3}{*}{ Height categories } & normal & 20 & 55.6 \\
\hline & short & 15 & 41.7 \\
\hline & tall & 1 & 2.8 \\
\hline \multirow[t]{4}{*}{ Weight categories } & normal & 23 & 63.9 \\
\hline & obese & 9 & 25.0 \\
\hline & over Weight & 3 & 8.3 \\
\hline & under Weight & 1 & 2.8 \\
\hline
\end{tabular}

Table (5) Gross hormone distribution among the studied cases.

\begin{tabular}{lcc}
\hline & Rang & Mean \pm SD \\
\hline Gross hormone $(\mathbf{n g} / \mathbf{m L})$ & $0.04-2.80$ & $0.76 \pm 0.86$ \\
\hline
\end{tabular}

Table (6) Provocated growth hormone distribution among the studied cases.

\begin{tabular}{lcc}
\hline & Rang & Mean \pm SD \\
\hline Provocated growth hormone $(\mathbf{n g} / \mathbf{m L})$ & $1.17-14.60$ & $5.28 \pm 2.81$ \\
\hline
\end{tabular}

Table (7) Provocated growth hormone categories distribution among the studied cases.

\begin{tabular}{llcc}
\hline & & No. & \% \\
\hline Provocated & borderline & 10 & 27.8 \\
growth hormone & normal & 6 & 16.7 \\
categories & sub normal & 20 & 55.6 \\
\hline
\end{tabular}

Table (8) Some laboratory parameters distribution among the studied cases.

\begin{tabular}{lcc}
\hline & Rang & Mean \pm SD \\
\hline protein in24 h urine(gm/dl) & $3.5-8.0$ & $6.22 \pm 1.44$ \\
Urea (mg/dl.) & $17.0-33.0$ & $26.80 \pm 4.98$ \\
Creat (mg/dl.) & $0.30-0.90$ & $0.64 \pm 0.19$ \\
Haemoglobin (gm/dl.) & $7.0-12.3$ & $10.59 \pm 1.15$ \\
Triglycerides (mg/dl.) & $152-173$ & $160.80 \pm 6.14$ \\
Cholesterol (mg/dl.) & $185-231$ & $212.40 \pm 12.70$ \\
\hline
\end{tabular}

Table (9) Cumulative Dose Of Steroid Distribution Among The Studied Cases.

\begin{tabular}{lcc}
\hline & Rang & Mean \pm sd \\
\hline Cumulative dose of steroid & $0.002-2.610$ & $1.06 \pm 0.66$ \\
\hline
\end{tabular}


Table (10) Comparison between corticosteroid and corticosteroid with other immunosuppressive drugs group regarding demographic data.

\begin{tabular}{|c|c|c|c|c|c|c|}
\hline & & & $\begin{array}{c}\text { corticosteroid } \\
\text { group }\end{array}$ & $\begin{array}{l}\text { corticosteroid } \\
\text { with other } \\
\text { immunosuppres } \\
\text { sive drugs } \\
\text { group } \\
\end{array}$ & t.test & $\begin{array}{c}\text { P. } \\
\text { value }\end{array}$ \\
\hline \multirow[t]{2}{*}{$\begin{array}{l}\text { Age } \\
\text { (years) }\end{array}$} & \multicolumn{2}{|c|}{ Mean \pm SD } & $7.333 \pm 2.44$ & $8.292 \pm 2.08$ & -1.163 & 0.253 \\
\hline & female & $\begin{array}{l}\text { No. } \\
\%\end{array}$ & $\begin{array}{c}9 \\
37.5 \%\end{array}$ & $\begin{array}{c}5 \\
41.7 \%\end{array}$ & $\begin{array}{c}X^{2} \\
0.058\end{array}$ & 0.809 \\
\hline Sex & male & $\begin{array}{l}\text { No. } \\
\%\end{array}$ & $\begin{array}{c}15 \\
62.5 \%\end{array}$ & $\begin{array}{c}7 \\
58.3 \%\end{array}$ & & \\
\hline \multicolumn{2}{|c|}{ age of onset of the disease (years) } & Mean \pm SD & $3.979 \pm 2.00$ & $4.500 \pm 1.72$ & $\begin{array}{c}\text { t.test } \\
-0.769\end{array}$ & 0.447 \\
\hline $\begin{array}{l}\text { family } \\
\text { history of } \\
\text { Nephrotic } \\
\text { syndrome }\end{array}$ & $\begin{array}{l}\text { negative } \\
\text { positive }\end{array}$ & $\begin{array}{l}\text { No. } \\
\% \\
\text { No. } \\
\%\end{array}$ & $\begin{array}{c}22 \\
91.7 \% \\
2 \\
8.3 \%\end{array}$ & $\begin{array}{c}12 \\
100.0 \% \\
0 \\
.0 \%\end{array}$ & $\begin{array}{c}X^{2} \\
1.059 a\end{array}$ & .303 \\
\hline \multicolumn{2}{|c|}{ duration of corticosteroid (years) } & Mean \pm SD & $3.35 \pm 2.088$ & $3.79 \pm 1.90$ & $\begin{array}{c}\text { t.test } \\
-0.610\end{array}$ & 0.546 \\
\hline $\begin{array}{l}\text { response to } \\
\text { corticosteroid }\end{array}$ & $\begin{array}{l}\text { complete } \\
\text { remission } \\
\text { infrequent } \\
\text { relapse } \\
\text { corticosteroid } \\
\text { dependant } \\
\end{array}$ & $\begin{array}{l}\text { No. } \\
\% \\
\text { No. } \\
\% \\
\text { No. } \\
\%\end{array}$ & $\begin{array}{c}1 \\
4.2 \% \\
2 \\
8.4 \% \\
21 \\
87.5 \% \\
\end{array}$ & $\begin{array}{c}0 \\
.0 \% \\
1 \\
8.3 \% \\
11 \\
91.7 \%\end{array}$ & $\begin{array}{c}X^{2} \\
1.266\end{array}$ & .737 \\
\hline
\end{tabular}

Table (11) Comparison between Steroid group and Steroid with other immunosuppressive drugs group regarding anthropometric measurements.

\begin{tabular}{|c|c|c|c|c|c|c|}
\hline & & & Steroid group & $\begin{array}{c}\text { Steroid with other } \\
\text { immunosuppressive } \\
\text { drugs group }\end{array}$ & t.test & P. value \\
\hline \multirow{7}{*}{$\begin{array}{l}\text { Height (cm.) } \\
\text { Height distribution }\end{array}$} & \multicolumn{2}{|c|}{ Mean \pm SD } & $106.79 \pm 29.90$ & $111.33 \pm 28.34$ & \multirow{7}{*}{$\begin{array}{c}-0.437- \\
X^{2} \\
2.925\end{array}$} & \multirow{7}{*}{$\begin{array}{c}0.665 \\
.232\end{array}$} \\
\hline & normal & No. & 15 & 5 & & \\
\hline & & $\%$ & $62.5 \%$ & $41.7 \%$ & & \\
\hline & \multirow[t]{2}{*}{ short } & No. & 9 & 6 & & \\
\hline & & $\%$ & $37.5 \%$ & $50.0 \%$ & & \\
\hline & \multirow[t]{2}{*}{ tall } & No. & 0 & 1 & & \\
\hline & & $\%$ & $.0 \%$ & $8.3 \%$ & & \\
\hline WT (kg) & \multicolumn{2}{|c|}{ Mean \pm SD } & $32.17 \pm 18.63$ & $31.92 \pm 7.99$ & $\begin{array}{l}\text { t.test } \\
0.044\end{array}$ & 0.965 \\
\hline \multirow[t]{8}{*}{ weight distribution } & \multirow[t]{2}{*}{ normal } & No. & 15 & 8 & \multirow{8}{*}{$\begin{array}{l}X^{2} \\
.522\end{array}$} & \multirow[t]{8}{*}{.914} \\
\hline & & $\%$ & $62.5 \%$ & $66.7 \%$ & & \\
\hline & \multirow[t]{2}{*}{ obese } & No. & 6 & 3 & & \\
\hline & & $\%$ & $25.0 \%$ & $25.0 \%$ & & \\
\hline & over & No. & 2 & 1 & & \\
\hline & weight & $\%$ & $8.3 \%$ & $8.3 \%$ & & \\
\hline & under & No. & 1 & 0 & & \\
\hline & weight & $\%$ & $4.2 \%$ & $.0 \%$ & & \\
\hline \multirow[t]{2}{*}{ BMI $\left(\mathrm{kg} / \mathrm{m}^{2}\right)$} & \multirow{2}{*}{\multicolumn{2}{|c|}{ Mean \pm SD }} & & & t.test & 0.747 \\
\hline & & & $28.67 \pm 15.42$ & $30.53 \pm 17.55$ & -0.325 & \\
\hline
\end{tabular}


Table (12) Comparison between corticosteroid group and corticosteroid with other immunosuppressive drugs group regarding growth hormone.

\begin{tabular}{|c|c|c|c|c|c|c|}
\hline & & & corticosteroid group & $\begin{array}{l}\text { corticosteroid with } \\
\text { other } \\
\text { immunosuppressive } \\
\text { drugs group }\end{array}$ & t.test & P. value \\
\hline $\begin{array}{l}\text { growth } \\
\text { (ng/mL) }\end{array}$ & hormone & Mean \pm SD & $0.60 \pm 0.63$ & $1.08 \pm 1.16$ & $-1.615-$ & 0.016 \\
\hline
\end{tabular}

Table (13) Comparison between corticosteroid group and corticosteroid with other immunosuppressive drugs group regarding propagated growth hormone.

\begin{tabular}{|c|c|c|c|c|c|}
\hline & & corticosteroid group & $\begin{array}{l}\text { corticosteroid with } \\
\text { other } \\
\text { immunosuppressive } \\
\text { drugs group }\end{array}$ & t.test & P. value \\
\hline $\begin{array}{l}\text { provocated Growth } \\
\text { hormone }(\mathrm{ng} / \mathrm{mL})\end{array}$ & Mean \pm SD & $5.21 \pm 1.74$ & $5.307 \pm 3.25$ & 0.095 & 0.025 \\
\hline
\end{tabular}

Table 14: Comparison between Steroid group and Steroid with other immunosuppressive drugs group regarding provocated Growth hormone distribution.

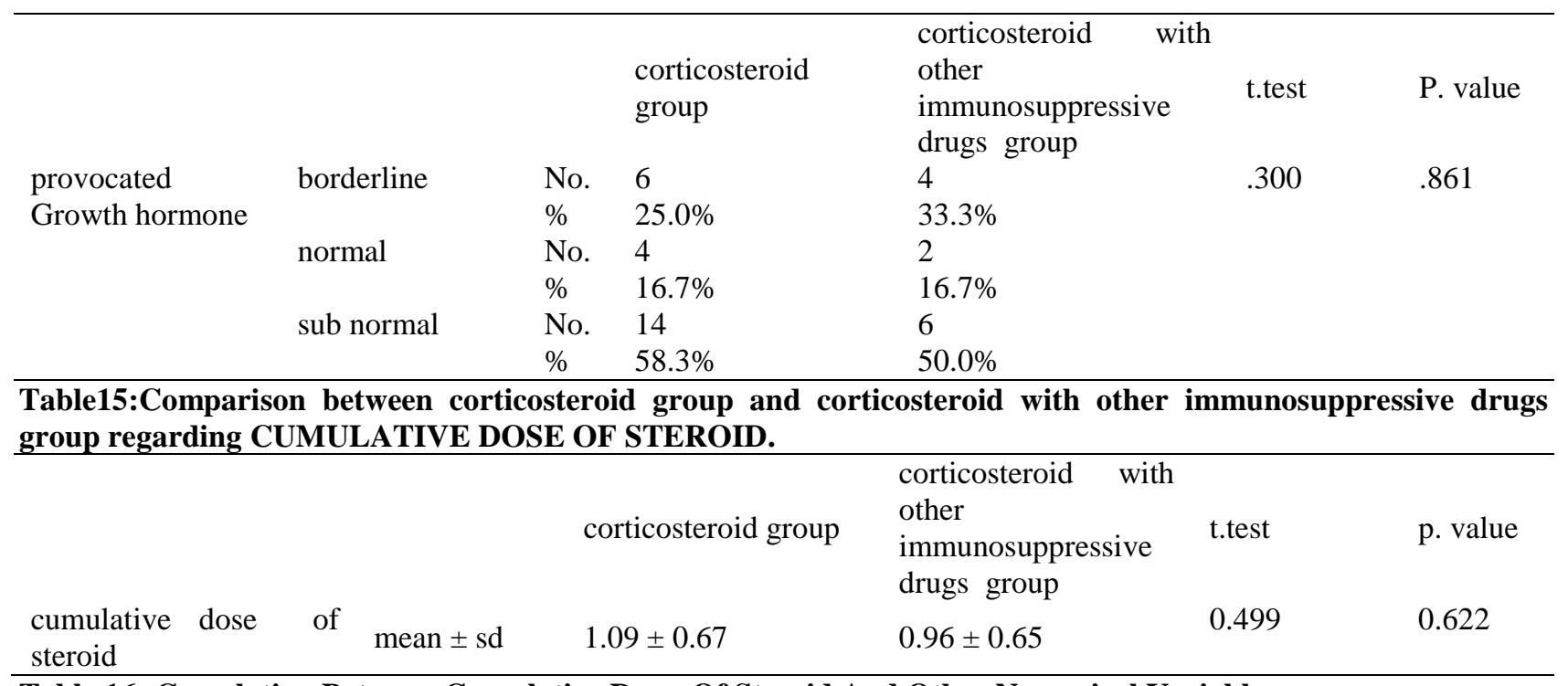

Table 16: Correlation Between Cumulative Dose Of Steroid And Other Numerical Variables.

\section{Correlation}

age of onset of the disease * CUMULATIVE DOSE OF STEROID

Duration of drugs $*$ cumulative dose of steroid

$\mathrm{Ht} *$ cumulative dose of steroid

$\mathrm{Wt} *$ cumulative dose of steroid

Bmi * cumulative dose of steroid

Growth hormone * cumulative dose of steroid

provocated Growth hormone Gross hormone * CUMULATIVE DOSE OF STEROID

\begin{tabular}{ll}
\multicolumn{3}{l}{ Pearson's correlation } \\
$\mathbf{r}$ & $\mathbf{p}$ \\
$-0.082-$ & 0.674 \\
0.246 & .198 \\
-0.070 & 0.019 \\
0.277 & 0.046 \\
0.163 & 0.400 \\
-0.404 & 0.030 \\
-0.288 & 0.010 \\
&
\end{tabular}




\section{Discussion}

The age of the children evaluated in this research varied from 3.5 to 13 years, with a mean $(7.652 .34)$.

This is in line with the findings of Moon et al. (5), who looked into the age of children with NS and found that the average age was 10.73 .1 years.

In our situations, we discovered a male majority during the study sex distribution (61.1 percent ).

Our findings were backed up by Rhuma et al., (6) and Ephraim et al., (7), who found that men were more impacted by NS than females.

The majority of our NS patients $(66.7 \%)$ were on corticosteroid medication, while 33.3 percent were on corticosteroid plus immunosuppressive medication, according to our research.

Complete remission was $1(2.8 \%)$, steroid dependent was $20(55.5 \%)$, rare recurrence was 3 $(8.4 \%)$, and corticosteroid resistant was 12 in our research (33.3).

According to Sahana (8), 63 percent of patients were in relapse.

According to the findings of the present research, small stature accounted for 15 percent of the cases analysed (41.7 percent ).

This is in line with Oliveira and Belangero's (9), who discovered that the majority of patients exhibited a height deficiency.

This is also in accord with Constantinescu et al. (10) who wanted to show that children with NS had height impairments. The importance of linear growth in early development cannot be overstated. Social stigma, anxiety, and emotional ill health accompany growth retardation in children. As a result, it's critical to maximise growth. The discovery that alternate-day steroids have an effect on linear development might lead to a shift in practise, with the early use of steroid sparing medicines to avoid growth retardation.

However, findings contradicting these and the current research have been frequently published in the literature. Simmonds et al. (11) observed that low to moderate dosages of prednisolone had no impact on linear growth in a comparable cohort of children at Great Ormond Street Hospital in the United Kingdom. This was true even at dosages as low as $0.75 \mathrm{mg} / \mathrm{kg}$, whereas dosages higher than $0.75 \mathrm{mg} / \mathrm{kg}$ had a tiny but substantial influence on growth velocity. In prepubertal children with nephrotic syndrome, Polito et al. (12) showed comparable effects with alternate-day corticosteroids.

During the evaluation of renal functions, we discovered that urea levels in the examined patients varied from 17 to $33 \mathrm{mg} / \mathrm{dl}$, with a mean of 26.804 .98 $\mathrm{mg} / \mathrm{dl}$. Creatinine levels in the examined patients varied from 0.30 to $0.90 \mathrm{mg} / \mathrm{dl}$, with a mean of $0.64 \mathrm{mg} / \mathrm{dl}$.

This is in accord with Amin et al. (13) who showed no statistically significant difference in blood urea and serum creatinine between the patient group (children with nephrotic syndrome) and the control group.
In this research, the distribution of protein in 24 hour urine varied from 3.5 to $8(\mathrm{gm} / \mathrm{dl})$, with a mean of 6.221.44. Haemoglobin levels in the examined patients varied from 7 to $12.3 \mathrm{gm} / \mathrm{dl}$, with a mean of 10.59 $\mathrm{gm} / \mathrm{dl}$. Triglyceride levels in the examined patients varied from 152 to $173 \mathrm{mg} / \mathrm{dl}$, with a mean of 160.80 $\mathrm{mg} / \mathrm{dl}$. Cholesterol levels in the examined patients varied from 185 to $231 \mathrm{mg} / \mathrm{dl}$, with a mean of $(212.40$ 12.70).

Patients with nephrotic syndrome have an accelerated catabolism state, which is accompanied by increased protein intake, loss, and malnutrition (14). They are accompanied by inflammatory hypoproteinemia and hyperlipidemia as the illness progresses (15). Furthermore, the body's nutritional metabolism is disrupted, and long-term malnutrition has a negative impact on patients' prognoses (16). Hypoproteinemia is treated with exogenous human albumin infusions for symptomatic support, according to previous results; nevertheless, albumin is costly (17). There are also certain infusion issues that result in albumin loss, despite the fact that the overall time spent maintaining plasma protein after infusion is minimal (18). As a result, it is unable to effectively treat hypoproteinemia and malnutrition in the body. In recent investigations, traditional Chinese medicine has also been used (19).

The G.H distribution in the examined cases was found to vary between 0.04 and $2.80 \mathrm{ng} / \mathrm{ml}$, with a mean of 0.760 .86 . The distribution of elicited growth hormone in the examined patients varied from 1.17 to $14.60(\mathrm{ng} / \mathrm{ml})$, with a mean of 5.28 2.81. According to this research, the distribution of activated growth hormone categories among the analysed patients was as follows: borderline $(10.78 \%)$, normal $(6.17 \%)$, and subnormal (20\%). (55.6 percent).

This is in line with the findings of Dai et al. (20), who discovered that growth hormone levels in NS patients are abnormal.

There was a statistically significant negative connection between cumulative steroid dosage and mortality in the present trial (growth hormone and provocated Growth hormone).

This is consistent with the findings of Valavi et al. (21) who showed that participants with higher prednisolone cumulative doses had a greater drop in height $(\mathrm{p}=0.001)$. They came to the conclusion that cumulative prednisolone doses had a deleterious influence on linear development.

Steroids reduce osteoblastogenesis in the bone marrow and promote osteocyte and osteoblast death, both of which contribute to a reduction in bone production. Some definitions, such as osteonecrosis, aseptic necrosis, and avascular necrosis, might be explained by the buildup of apoptotic osteocytes. The deleterious impact of steroid usage on bone mass and short-term development varies by steroid type and dosage, and happens most often during the first six months of medication. Trabecular bones are thought to be more impacted than cortical ones (22). 
Our findings correspond with those of Mohan and Kanitkar (23) who studied the relationship between growth and the cumulative dosage of steroids in children with nephrotic syndrome. A retrospective analysis of 35 children with NS was performed. They discovered that the cumulative steroid dosage causes growth retardation.

In a comparable research, both boys and girls' development, as measured by changes in height, deteriorated dramatically as they grew older. Height and treatment duration were shown to have a strong unfavourable relationship (24).

Another research found that being overweight or obese protects SSNS against glucocorticoid-related development retardation (25)

Glucocorticoids are frequently effective in children with little change nephrotic syndrome. In most cases, daily glucocorticoid treatment may be lowered to alternate-day treatment in a very short period of time. Development failure was only detected in children who had daily steroid medication for a long time, but alternate-day steroids were not linked to severe growth impairment (26), and growth hormone treatment was not recommended (rhGH). However, in steroiddependent nephrotic syndrome, rhGH has been shown to have a considerable favourable influence on height, bone mineralization, and body composition, as well as a relative acceleration of bone age (27). Because of the large improvement in growth associated with reduced usage of steroids, steroid sparing medicines (such as alkylating agents) are a viable option for children with nephrotic syndrome who exhibit evidence of slowed development (28).

At this time, the best method to minimise growth impairment is to avoid an excessively lengthy course of corticosteroid medication, to supply appropriate calories and proteins, to assess development on a regular basis, and to attempt to reduce psychological stress.

Longitudinal studies reveal the impact of corticosteroid cumulative dosage on linear growth better. Take, for example, Emma et al(29) .'s research on children with NS. They discovered that longer therapy was linked to a greater risk of growth retardation. These findings were comparable to the current findings in that long-term unfavourable consequences were observed.

Ribeiro et al. (30) found that long-term corticosteroids, especially at higher dosages, had an effect on height and spinal bone density.

The natural production of growth hormone may be diminished or mediated by somatostatin after highdose steroid therapy, and growth hormone stimulation tests may be unable to achieve an acceptable response in certain situations. Valavi et al., Valavi et al., Valavi et al (21).

4.Conclusion

The majority of children with nephrotic syndrome have a height deficiency. Children with nephrotic syndrome may have growth retardation as a result of chronic steroid therapy. In most instances of NS, growth hormone levels are below normal. Corticosteroid cumulative doses have a negative impact on linear growth.

\section{References}

[1] OM. Akchurin, AJ. Kogon, J. Kumar . Approach to growth hormone therapy in children with chronic kidney disease varies across North America: The Midwest Pediatric Nephrology Consortium report. BMC Nephrol.vol.22,pp.18: $181,2017$.

[2] SN.Uwaezuoke Steroid-sensitive nephrotic syndrome in children: Triggers of relapse and evolving hypotheses on pathogenesis. Italian Journal of Pediatrics.vol.4,pp.22:24,2015.

[3] E .Valavi , M. Aminzadeh, P,Amouri, A,Rezazadeh, M. Beladi-Mousavi Effect of prednisolone on linear growth in children with nephrotic syndrome. Jornal de Pediatria. Vol.44,pp. 25:26,2018.

[4] A.Madani, S. Umar, R. Taghaodi, N. Hajizadeh, A .Rabbani, H. Z-Mehrjardi The Effect of Longterm Steroid Therapy on Linear Growth of Nephrotic Children. Iranian Journal of Pediatrics.vol.21(1).pp,21-27,2011.

[5] R. J.Moon, R. D.Gilbert, A. Page Children with nephrotic syndrome have greater bone area but similar volumetric bone mineral density to healthy controls. Bone.vol.58,pp. 108-113. doi:10.1016/j.bone..10.012,2014.

[6] NR. Rhuma, AS. El Boeshi, LT. Sabei. "A descriptive retrospective study on children with newly diagnosed nephrotic syndrome presented to Tripoli Children Hospital during the period between Jan. to Dec. 2014." Libyan International Medical University Journal.vol. ;1(1),pp. 45-57,2016.

[7] R K .Ephraim, R C. Brenyah, F B. Osei . Demographic, Clinical and Therapeutic Characteristics of Children Aged 0-15 years with Nephrotic Syndrome: A Retrospective Study of the Komfo Anokye Teaching Hospital, Kumasi, Ghana Asian Journal of Medicine and Health(AJMAH).vol.5(2),pp.19,2017.

[8] KS. Sahana, Clinical Profile of Nephrotic Syndrome in Children". Journal of Evolution of Medical and Dental Sciences.vol.3(4),pp. 863$70,2014$.

[9] de C. Oliveira, V. M. S. Belangero Crescimento e composição corporal em crianças e adolescentes com síndrome nefrótica córticodependente. Jornal Brasileiro de Nefrologia.vol.31(4),pp.252-257,2009.

[10] AR .Constantinescu, S. Maruñ̃. Â£elu, E .Velis, TO. Bizerea-Moga, MC. Almaguer. Strategies to Minimize Growth Retardation in Children with Steroid-Sensitive Nephrotic Syndrome. J Clin Exp Nephrol Vol.4 No,pp.2: 76,2019. 
[11] Simmonds, N. Grundy, R .Trompeter, K .Tullus Long-term steroid treatment and growth: a study in steroid-dependent nephrotic syndrome. Arch Dis Child.vol.9,pp.95:146,2010.

[12]C. Polito, MR. Oporto, SF. Totino. Normal growth of nephrotic children during long-term alternate-day prednisone therapy. Acta Paediatr Scand.vol.75(2),pp.245-50,1986.

[13] EK .Amin, MA. El-Gamasy, DM. Shokry. Study of glucocorticoid receptors in $\mathrm{T}$ lymphocytes (CD3/GCR) as predictor of steroid responsiveness in Egyptian children with idiopathic nephrotic syndrome. Saudi J Kidney Dis Transp.vol.1;29,pp.893-901,2018.

[14] M .Fragiadaki, M .Lannoy, M. Themanns, B. Maurer, WN. Leonhard, DJ.Peters R .Moriggl and AC. Ong: STAT5 drives abnormal proliferation in autosomal dominant polycystic kidney disease. Kidney Int.vol. 91,ppp.75586,2017.

[15] EM .Othman, M. Naseem, E.Awad, T. Dandekar and $\mathrm{H}$. Stopper The plant hormone cytokinin confers protection against oxidative stress in mammalian cells. PLoS One.vol.11,pp. e0168386,2016.

[16]DFK. Rawn, M .Dowd, MJS .Scuby, PP. Pantazopoulos, M. Feeley Polychlorinated Biphenyls and Polychlorinated Dioxins-Furans in Lake Trout and Whitefish Composite Samples from Commercial Fisheries in Lakes Erie, Huron, and Superior. J Food Prot. .vol.80(8),pp.1228-1238,2017.

[17] P. Bu, Y. Le, Y. Zhang and X .Cheng Hormonal and chemical regulation of the Glut 9 transporter in mice. J Pharmacol Exp Ther.vol. 360,pp.206214,2017.

[18] Y. Liu, EH. Dutra, EJ .Reichenberger and IP. Chen Dietary phosphate supplement does not rescue skeletal phenotype in a mouse model for craniometaphyseal dysplasia. J Negat Results Biomed.vol.22,pp. 15:18,2016.

[19] J .Batra, RS. Buttar, P .Kaur, J. Kreimerman and ML. Melamed FGF-23 and cardiovascular disease: Review of literature. Curr Opin Endocrinol Diabetes Obes.vol.23,pp.423429,2016.

[20]G .Dai, D .Wang, H.Dong Effects of recombinant human growth hormone on protein malnutrition and IGF-1 and IL-2 gene expression levels in chronic nephrotic syndrome. Exp Ther Med.vol.15(5),pp.4167-4172,2018.

[21]E. Valavi, M .Aminzadeh, P. Amouri, A. Rezazadeh, M.Beladi-Mousavi Effect of prednisolone on linear growth in children with nephrotic syndrome. J Pediatr (Rio J) .vol.96(1),pp.117-124, 2020.

[22]R. S. Weinstein Glucocorticoid-induced osteonecrosis. Endocrine.vol.41(2),pp.183-190. https://doi.org/10.1007/s12020-011-9580-

0,2012 .
[23]R. Mohan, \& M.Kanitkar, Growth in Children with Steroid Sensitive Nephrotic Syndrome. Medical journal, Armed Forces India.vol.65(1),pp.4-6,.2009..

[24]Rees, SA. Greene, P. Adland, J .Jones, GB. Haycock, SPA. Rigden, M. Preece, R.Chantler Growth and endocrine function in steroid sensitive nephrotic syndrome. Arch Dis Child.vol. 63,pp.484-490,1988.

[25]JF. Bethany, S .Justine, SZ .Babette, BL.Mary Interactions between growth and body composition in children treated with high dose chronic corticosteroids. American Journal of Clinical Nutrition.vol.80,pp.1334-1341, 2004.

[26] AS.Abeyagunawardena Treatment of steroid sensitive nephrotic syndrome. Indian J Pediatr.vol.72,pp.763-769,2005.

[27]KY .Loke, HK. Yap, X.Zhou. Efficacy and safety of one year growth hormone therapy in steroid- dependent nephritic syndrome. J Pediatr.vol. 130(5),pp.793-9,1997.

[28]DS. Manish, M. Rebecca, R .Emma, BC.Godfrey Treatment of severe steroiddependant nephrotic syndrome (SDNS) in children with tacrolimus. Nephrology Dialysis Transplantation.vol.21,pp.1848-1854,2006.

[29]F. Emma, A.Sesto, G. Rizzoni Long-term linear growth of children with severe steroidresponsive nephrotic syndrome. Pediatr Nephrol.vol.18,pp.783-788,1997.

[30]D.Ribeiro, S.Zawadynski, LF.Pittet, T.Chevalley, E.Girardin, P.Parvex. Effect of glucocorticoids on growth and bo(2003) ne mineral density in children with nephrotic syndrome. Eur J Pediatr.vol.174,pp.911-7, 2015. 